\title{
Design of an Internationalization Model for Service Businesses in Border Areas in Medical Tourism
}

$\underline{\text { Anvar Ebrahimi1 }^{1} \text {, Ali Badi zadeh }}{ }^{2}$, kambiz Heidar Zadeh Hanazaei ${ }^{3}$

1. PhD Student, Department of entrepreneurship, Qazvin Branch, Islamic Azad University Qazvin, Iran,. Orchid Code: 00000003-1364-5898,

2. Assistant Professor, Management Group Qazvin Branch, Islamic Azad University Qazvin, Iran, (Corresponding Author), Orchid Code: 0000-0001-6269-4982, Tel: 087-35231355, Email: Abadizadeh@gmail.com

3. Assistant Professor, Business management group ‘University and Research ‘Islamic Azad University Tehran, Iran Orchid Code: 0000-0002-4592-3816

\begin{abstract}
Background and Aim: Development of medical tourism can contribute to employment boom in border areas. This study aimed to design an internationalization model for service businesses in border areas in relation to medical tourism industry.
\end{abstract}

Materials and Methods: The current study was performed by using a sequential explanatory mixed method. In qualitative stage, to identify principal components for internationalization of service businesses in border areas considering medical tourism, literature review and in-depth interview were carried out and to finalize the components, Delphi method was used. In quantitative stage we used exploratory factor analysis to evaluate the extracted model. Using SPSS and Smart PLS software, we used qualitative content analysis and structural equations for data analysis.

Results: For the identification of the principal components, a total of 20 in-depth interviews were performed and, for finalization of the model, 388 people were entered into the study. Seven dimensions as the model dimensions along with sub-components were extracted. The results showed that all the structural, behavioral and environmental factors were effective in the processes (amount: 0.83 and t: 45.12) and the results (amount: 0.75 and t: 10.34). Also all dimensional processes can affect the results (amount: 0.87 and t: 12.67). It can be concluded that casual accuracy relationships existing in the studied model are confirmed and it is a suitable model.

Conclusion: All the structural, behavioral and environmental factors can affect the results and processes. Also all dimensional processes can affect the results. The above mentioned model was confirmed. Therefore, to internationalize medical tourism, at first, the current status of the country's border areas should be compared to that of the model. In order to move forward for internationalization, necessary actions based on a multi-year plan should be considered.

Keywords: Business model, Tourism, Medical tourism, Internationalization, Border areas Received: Oct 16, 2020 Accepted: April 5, 2021

How to cite the article: Anvar Ebrahimi, Ali Badi zadeh, kambizhe Heidar Zadeh Hanazaei. Design of an Internationalization Model for Service Businesses in Border Areas in Medical Tourism. SJKU 2021: 26(6):24-37.

Copyright (C) 2018 the Author (s). Published by Kurdistan University of Medical Sciences. This is an open access article distributed under the terms of the Creative Commons Attribution-Non Commercial License 4.0 (CCBYNC), where it is permissible to download, share, remix, transform, and buildup the work provided it is properly cited. The work cannot be used commercially without permission from the journal 


\title{
طراحى مدل بينالملل سازى كسب وكار هاى خدماتى مناطق مرزى كشور در صنعت توريسم در مانى
}

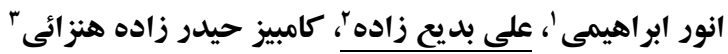

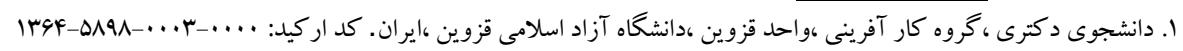

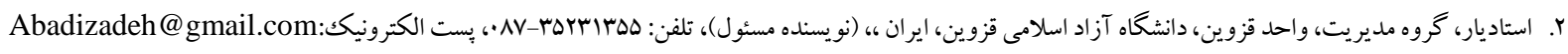

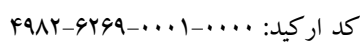

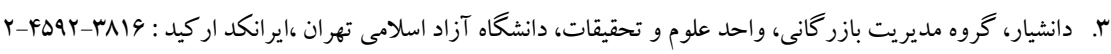

زمينه و هدف: توسعه توريسم درمانى مىتواند به رونق اشتغال در مناطق مرزى كمكك نمايد. اين مطالعه باهدف طراحى مدل بين الملل سازى كسبو كارهاى خدماتى مناطق مرزى كشور در صنعت توريسم درمانى انجام شد. مواد و روشها: مطالعه حاضر با رويكرد تر كيبى كمى - كيفى به صورت تبيينى متوالى (Sequential explanatory)انجام

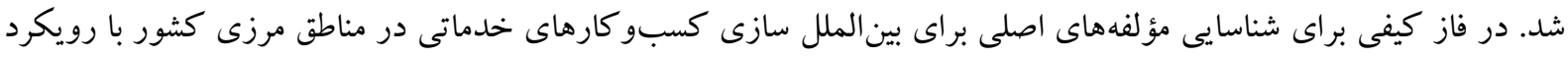
كُرشخگرى سلامت از مرور متون و مصاحبه عميق و براى نهايى سازى مؤلفه ها از روش دلفى استفاده شد. در فاز كمى از تحليل

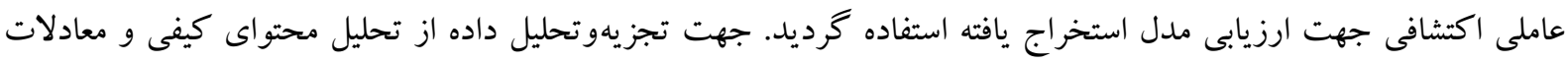

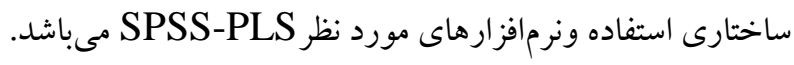

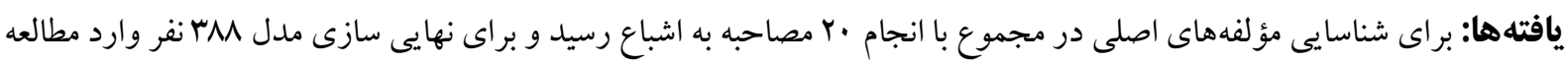

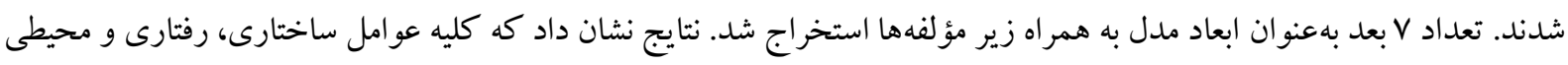

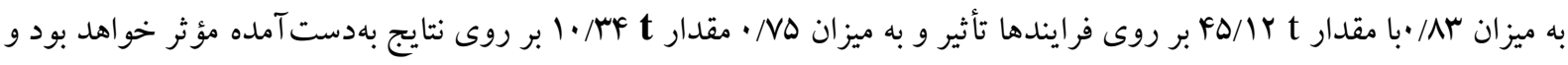

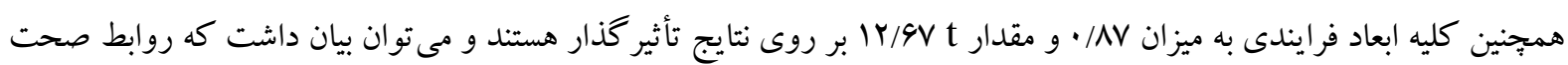
على موجود درمدل تحقيق تائيد شده و مدل نيز مناسب است.

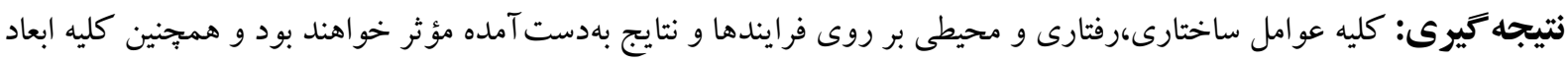

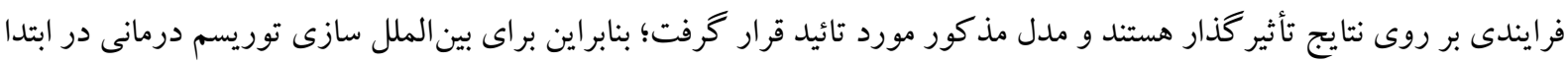

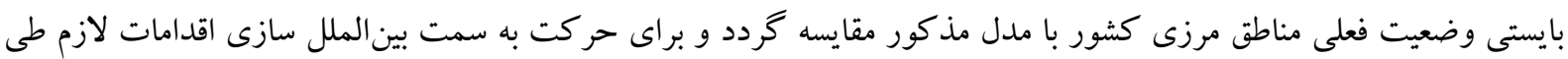
برنامه جند ساله به اجرا كذاشته شود. كلمات كليدى: مدل كسبو كار، توريسم، توريسم درمانى، بين المللى سازى، مناطق مرزى.

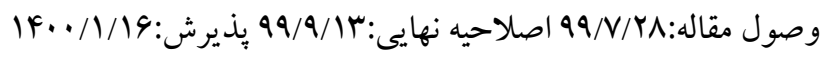


مى توان به گرُششكران بالقوه، اطلاعاتى درباره آنجه كه منطقه مشخص مىتواند ارائه دهد، عرضه نمود و آنها را نسبت به به به

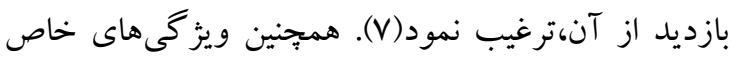
خدماتى بودن اين صنعت از جمله ناملموس بودن، نايايدارى،

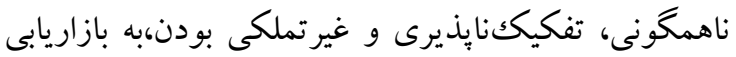
كردشگرى حساسيت ويزهاى داده است و لزوم استفاده از يكك مدل تر كيبى بين المللى را آشكار مى كند(A).به طور مثال

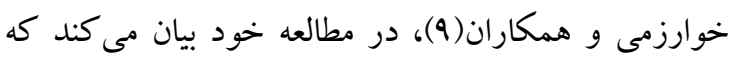

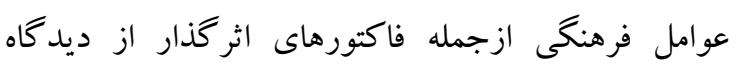
گردشخُران خارجى و مديران است.همجِنين حمايتهاى

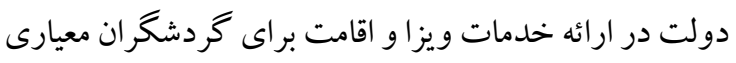

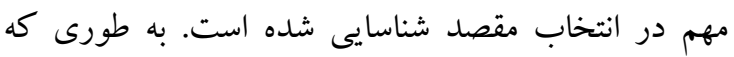

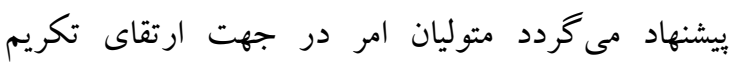

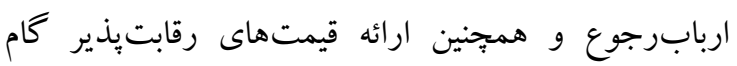
بردارند.مروتى شريف آبادى و اسديان اردكانى (·) به اين نتيجه رسيدند كه گردشخرى سلامت و توسعه آن در استان يزد نيازمند عزم جدى براى جلب رضايت بيمارانى است كه

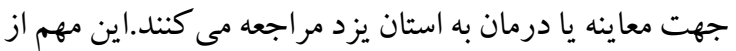
طريق سرمايه گذارى در تجهيز و بهروز كردن بيمارستانها و توسعه مهارت كادر بيمارستان مقدور خو اهد بود.

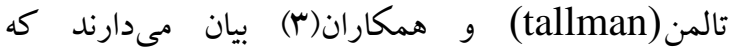
شركتهاى جندمليتى با استفاده از مدلهاى مناسب كسبوكار كه قابليتهاى متمايز و بازارهاى يويا رادارند،ارزش را به دست مى آورند. ازديخرعناصر كليدى براى يكك مدل تجارى جهانى مىتوان به بيشنهادهاى براى

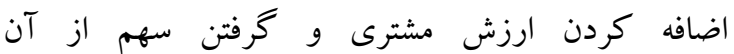

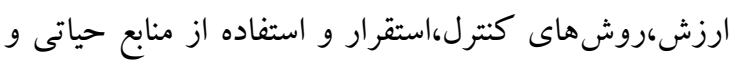

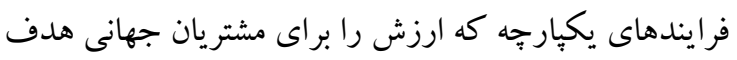

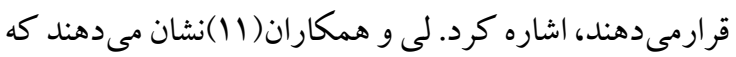
بازار نظارت بر محيطزيست، انطباق هنجارهاى كسبو كار و

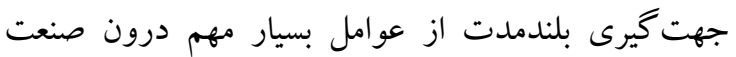

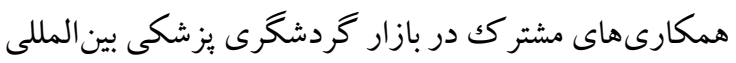

\section{مقدمه} كردشخرى يكى از سريعترين بخشهاى رشد اقتصادى در جهان امروزاست و فرصتهاى كسبو كار زيادى را ايجاد كرده است(1). يكى از بخشهاى موردتوجه در گردشخرى،

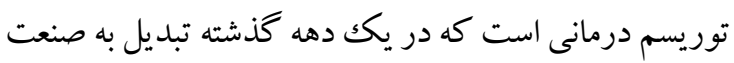
اصلى در برخى از كشورها مانند تركيه و هند شده است و در

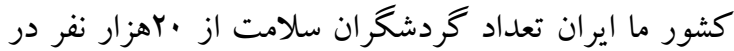

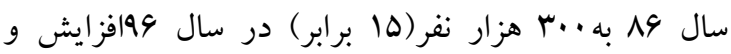

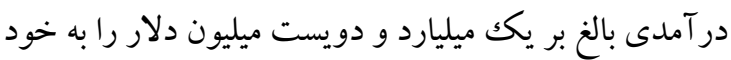
اختصاص داده كه نسبت به ساير كشورهاى فعال در اين زمينه

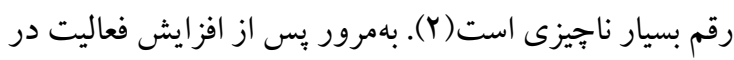

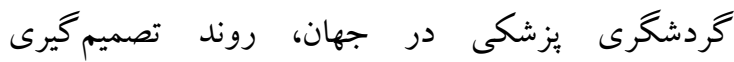
مصرف كنند كان در انتخاب يكك مر كز بهداشتى بين المللى بر درن اساس شاخصهاى استاندارد به طورفزايندهاى اهميت يافته

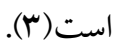
تجهيزات و وب سايتهاى بيمارستانهاى خصوصى كه به ترويج توريسم درمانى و گردشخرى بزشكى مى بردازند،

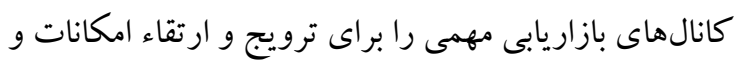

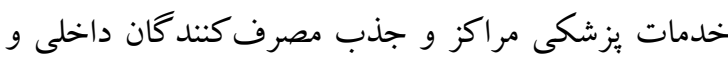
خارجى ايجاد مى كند (F). امروزه با توجه به تفاوت ارزى در بين كشورهاى مختلف و كاهش قيمت تمامشده دسترسى به خدمات درمانى براى كشورهاى با درآمد بالا، مسافرت از كشورهاى ثروتمند به كشورهاى كمدر آمد و متوسط براى دريافت مراقبت هاى بهداشتى ، به عنوان توريسم درمانى مورد توجه قرار گرفته است(ه). ازاينرو بازاريابى گردشخرى فرآيندى تعاملى، ميان عرضه كند گان و مصرف كنند كان (گردشگران) است كه طى آن كالاها و خدمات گردشكرى در محيطى كه خاص اين صنعت است؛ مبادله مىشود (9). با توجه به ويز گى هاى

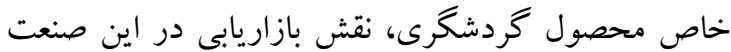

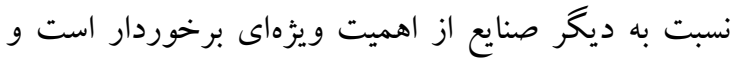

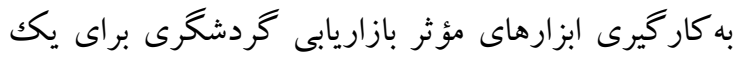

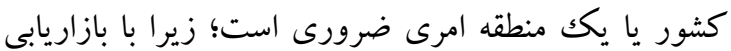


توريسم درمانى تخصص، تأليفات و فعاليتهاى علمى و ئزوهشى و تجربيات عملى در موضوع يزوهش دارند. روش

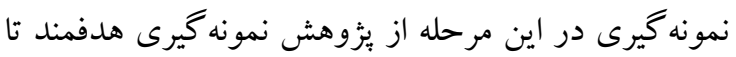

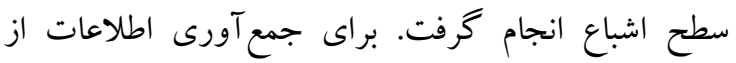

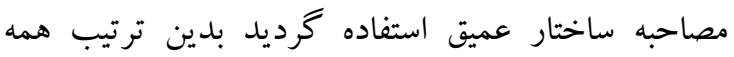
مصاحبهها ضبط و بلافاصله كلمه به كلمه نوشته مىشد. به به برديا

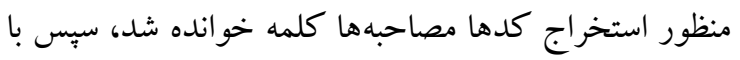

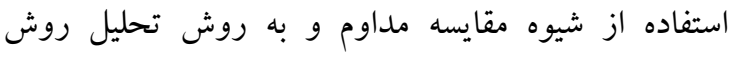
استقر ايى تجزيه تحليل شدند. براى كد گذذارى اوليه از كلمات

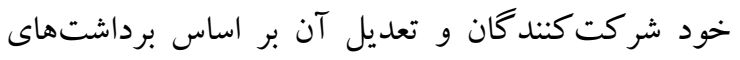

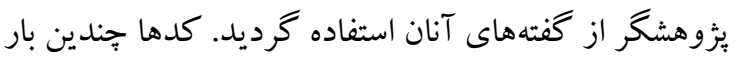
بازخوانى شدند تا بر اساس تشابه معنايى در زير تمها و تمهاى

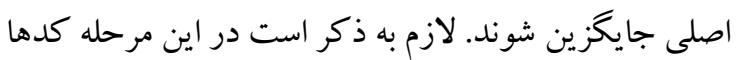
بر اساس ميزان تشابه، محدود و بر مبناى تفاوت معنايى و مفهومى طبقه بندى شدند. در اين مطالعه براى تعين روايى و

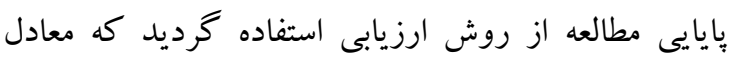
روايى و بايايى در تحقيقات كمى است. براى نهايى سازى

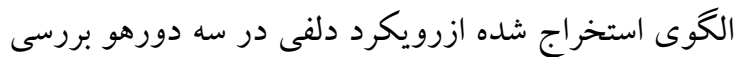

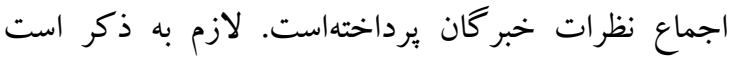
ضريب تو افق بين خبر كان بر اساس ضريب هماهنكى كندال، 0/94 بود كه نشاندهنده افزايش تو افق بين اعضاى خبر كان

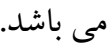
استفاده از متدلوزى كمى براى ارزيابى مدل بين الملل سازى كسبو كارهاى خدماتى در مناطق مرزى كشور با رويكرد

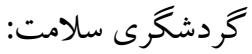
هدف اين بخش ارزيابى مدل استخراج يافته شده در جامعه

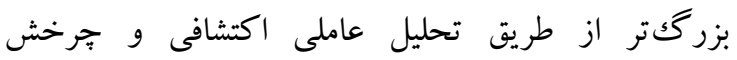
واريماكسمى باشد. جامعه آمارى بخش كمى اين تحقيق شامل تمامى مديران و كارشناسان صنعت توريسم درمانى

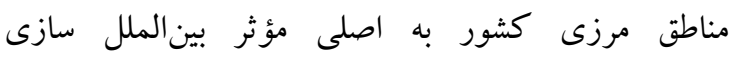
كسبو كارهاى خدماتى توريسم درمانى در مناطق مرزى كشور استفاده صورت سرشمارى بودند. در اين مطالعه از
بهواقع مىتوان گفت كه برنامهريزى براى توسعه مناطق

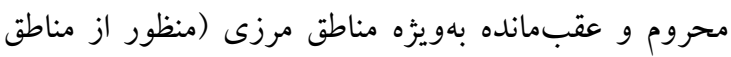
مرزى ،اصطلاحى است كه در جغرافياى سياسى از آن براى مشخص كردن مرزهاى جغرافيايى كشور استفاده مىشود و

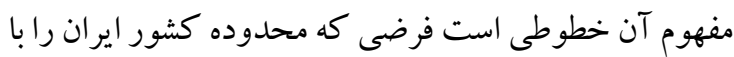
كشور هاى همسايه معين مى كند حنفى و خوشحال دستجردى

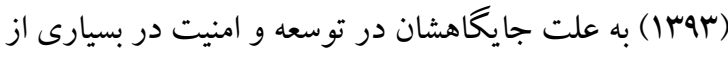

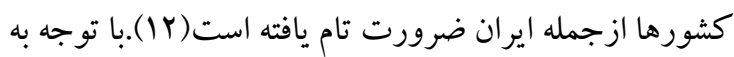
شكاف نظرى موجود و اهميت موضوع و به دليل اينكه ايران يكى از مراكز فعال گردشخرى سلامت در منطقه خاورميانه

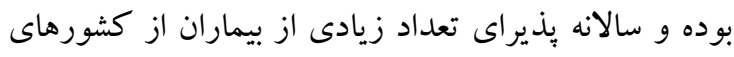
مختلف منطقه براى دريافت خدمات بزشكى است؛ بنابراين اين مطالعه با هدف ارائه مدل بين الملل سازى كسبو كارهاى

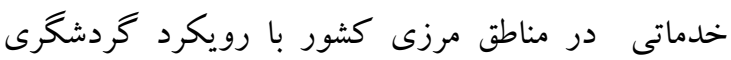

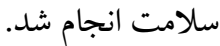

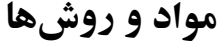
مطالعه حاضر با رويكرد تركيبى كمى - كيفى به صورت تبينى متوالى انجام شد. در فاز كيفى براى شناسايى مؤلفههاى اصلى براى بين الملل سازى كسبو كارهاى خدماتى در مناطق مرزى كشور با رويكرد گردشكرى سلامت از مرور

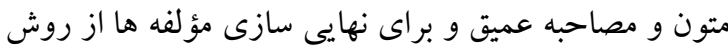
دلفى استفاده شد. در فاز كمى از تحليل عاملى اكتشافى جهت ارزيابى مدل استخر اج يافته استفاده گرديد. استفاده از متدولوزى كيفى براى شناسايى مؤلفهاى اصلى نمانى براى بين الملل سازى كسبو كارهاى خدماتى در مناطق مرزى كشور با رويكرد گردشخرى سلامت: در مطالعه حاضر براى شناسايى مؤلفهاى اصلى بين الملل سازى كسبو كار در گردشخرى سلامت به صورت كيفى از نوع تحليل محتو اي قراردادى عرفى (Customary Contract Content) يثزوهش شامل صاحبنظرانى هستند كه در زمينه صنعت 
ميز ان اهميت هر مؤلفه از طيف ليكرت له تايى (بسيار كم، كم، متوسط، زياد، بسيار زياد) استفاده شد. جهت تجزيهوتحليل داده از تحليل محتواى كيفى و معادلات ساختارى استفاده و نرمافزارهاى موردنظر SPSS-PLS مىباشد.

يافته ها

براى شناسايى مؤلفههاى اصلى براى بين الملل سازى كسبو كارهاى خدمات گردشخرى در مناطق مرزى كشور، در مجموع با انجام ·r مصاحبه با صاحبنظر ان اين حوزه به اشباع رسيد. مصاحبه شوند كان اكثراً مرد و داراى سابقه كارى بالاى •ال سال بودند. ساير جزييات در ضميمه جدول ا آمده
يرسشنامه محقق ساخته براى بررسى ديدگاه هاى مديران و كارشناسان در زمينه مؤلفههاى شد. اين برسشنامه بر اساس نتايج فاز قبلى مطالعه طراحى گرديد كه تبديل به يرسشنامه اوليه شد. جهت تعيين روايى برسشنامه از روش لاوشه استفادهشد كه در آن براى بررسى روايى محتوايى به شكل

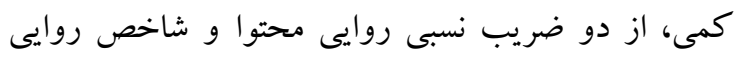
محتوا ( Content Validity Ratio)، استفاده شد كه يرسشنامه نهايى در اختيار ·ب نفر از مديران و كارشناسان صنعت توريسم درمانى قرار داده شد و مقدار آلفاى كرونباخ 0/79به دست آمد. يرسشنامه نهايى تدوين شده شامل دو بخش؛ اطلاعات مربوط به مشخصات فردى و دمو گرافيك افراد و مؤلفههاى بين المللى سازى است. جهت نمره گذارى

جدول شماره ا: مشخصات مصاحبه شوندكان

\begin{tabular}{|c|c|c|c|}
\hline$\wedge$ & $\begin{array}{l}r \\
k\end{array}$ & رئيس رئيس اداره & ويز گى هاى سازمانى \\
\hline & $\begin{array}{l}v \\
r \\
0 \\
0\end{array}$ & 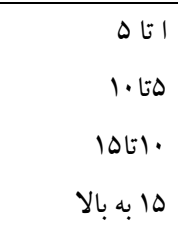 & سابقه كارى \\
\hline & ${ }^{i r}$ & زرد & جنسيت \\
\hline & $\begin{array}{l}f \\
\wedge \\
v \\
i\end{array}$ & $\begin{array}{r}\text { كمتر از ·r سال } \\
30-40-50 \\
40-\text { هسال به بالا }\end{array}$ & سن \\
\hline
\end{tabular}

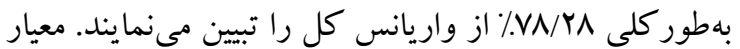
انتخاب شاخص، بهعنو ان يك شاخص براى عو امل، دارا بودن ارزش ويزه بالاتر از يك و همجنين بار عاملى •ه/· و بالاتر
جهت انجام مؤلفهاى اصلى و جرخش واريماكس استفاده شده كه تعداد V بعد به عنوان ابعاد مدل به همراه زير مؤلفه ها استخراج شد كه موردبررسى قرار گرفتند. اين V بعد 
هر يكك از اين شاخصها، عوامل مربوطه و ميزان بار عاملى آنها در جدول r نمايش دادهشده است.
به شرطى كه در ديخر عوامل كمتر از اين مقدار ظاهر شود بوده است و درنهايت VD شاخص موردنظر انتخاب گرديد.

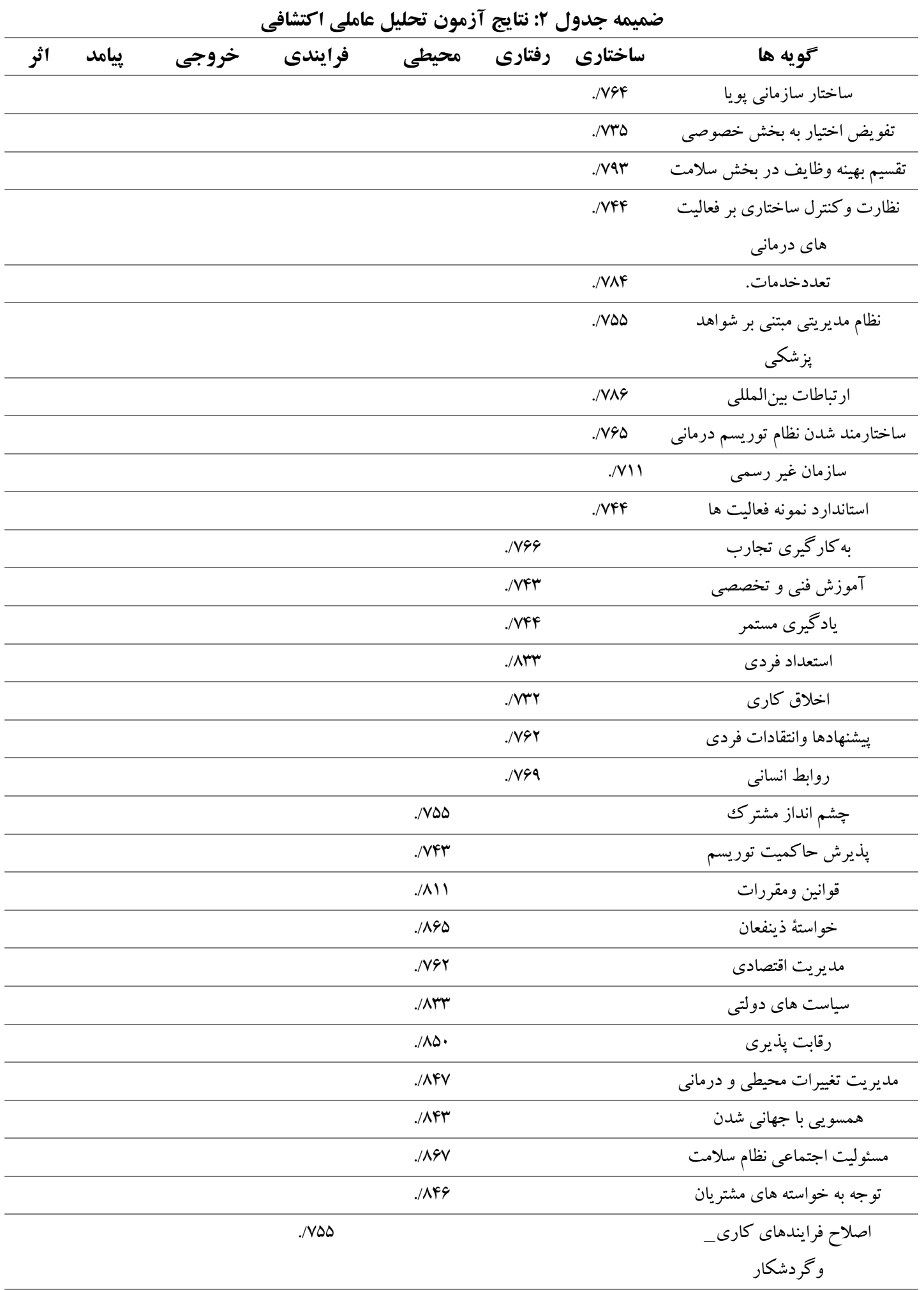

هجله علمى دانشكاه علوه يِشكى كردستان / دوره بيست و شش / آذر و دى م.ع|| 


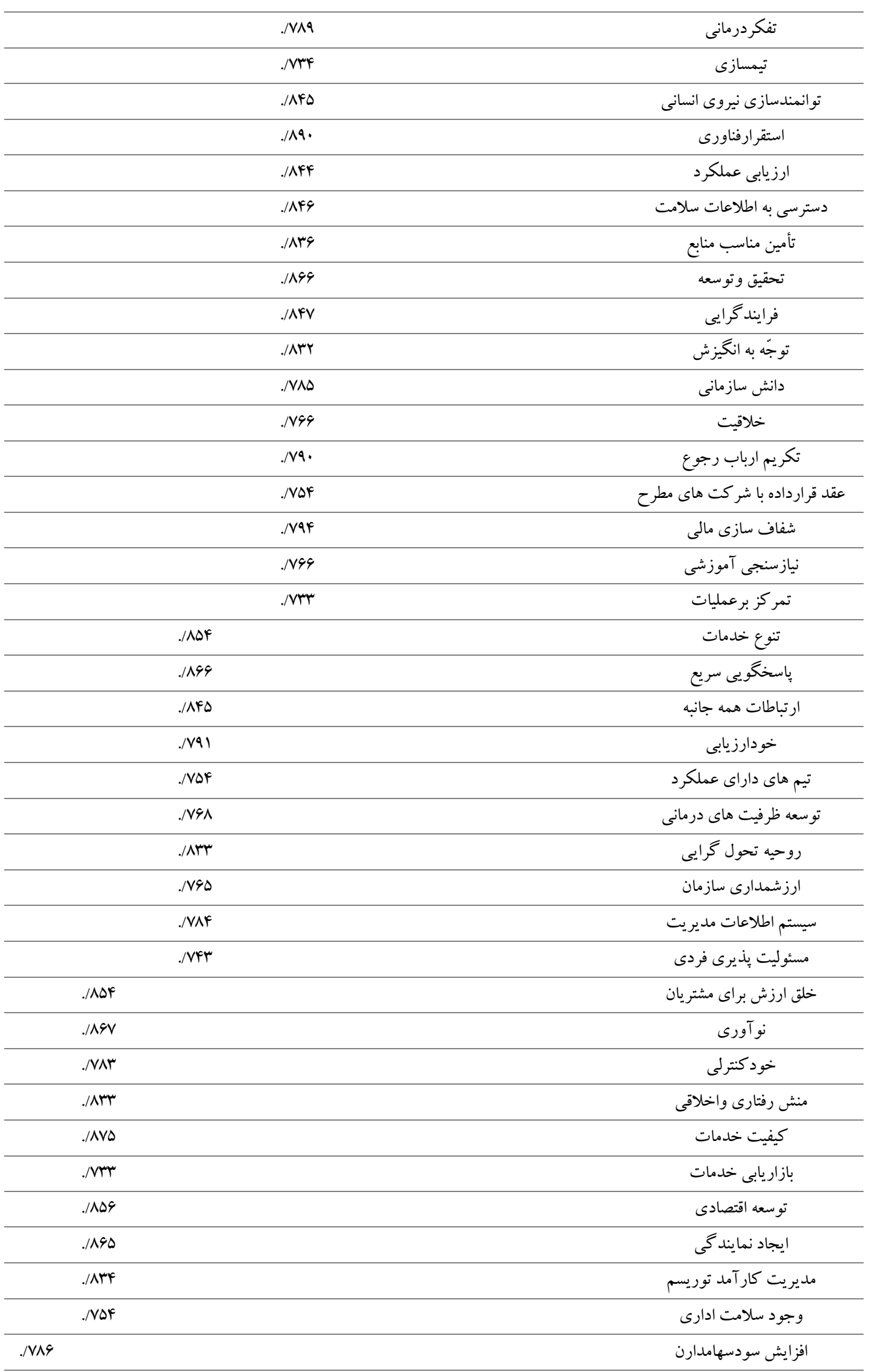

هبلم علمى دانشكاه علوه بِزشكى كردستان / دوره بيست و شش / آذر و دى م。ع|| 
اس طراصى ددل بين الملل سازى ...

\begin{tabular}{|c|c|c|c|c|c|c|c|}
\hline . VFF & & & & & & & برنامه ريزى جذب توريسم \\
\hline /AFr & & & & & & & افز ايش آزادى عمل \\
\hline.$/ \wedge \Delta 9$ & & & & & & & معرفى خدمات \\
\hline.$/ \wedge 9 V$ & & & & & & & حذف مقررات مازاد \\
\hline.$/ 111$ & & & & & & & اعضاى شايسته وهم افزايى \\
\hline.$/ V \Delta \Delta$ & & & & & & & تضمين خدمات \\
\hline.$/ 909$ & & & & & & & وجود سيستم مديريت مشترى \\
\hline$\cdot, \wedge 94$ & & & & & & & سرمايه گذارى برون مرزى \\
\hline F/rT & $F / \wedge r$ & $r / 9 r$ & $F / \Delta \Delta$ & r/ve & $F / 9 V$ & $\Delta / \mu F$ & مقادير ويزه اوليه كل \\
\hline $1 / 91$ & $r / \mu F$ & q/\%q & 1.194 & $14 / 90$ & $10 / F q$ & $r \Delta / \wedge F$ & درصد واريانس \\
\hline$\checkmark \wedge / Y \Lambda$ & $V \Delta / M V$ & 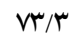 & $99 / 94$ & $\Delta \Delta / ৭ \Lambda$ & FI/rT & $r \Delta / A F$ & درصد تراكمى واريانس \\
\hline
\end{tabular}

با بار عاملى 909/ • مهمترين گويه عوامل اثر بودند. تحليل عاملى اكتشافى بر روى MM نفر از روش تحليل (ضميمه

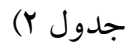

شاخص فورنل لاكر جهت بررسى شاخص روايى تشخيصى يا واكرا براى ابعاد مدل يُزوهش انجام شد كه نشان دادسازهها كاملاً از هم جدا مىباشند يعنى مقادير قطر اصلى براى هر متغير ينهان از همبستكى آن بعد با ساير بعدهاى ينهان انعكاسى موجود در مدل بيشتر است (ضميمه جدول ب).
همان طور كه مشاهده مىشود ارتباطات بين المللى با بار عاملى AV9/ • مهم ترين كويه عوامل ساختارى، استعداد فردى با بار عاملى سM//· مهمترين گويه عامل رفتارى، مسئوليت اجتماعى نظام سلامت با بار عاملى A\&V/•مهم ترين كويه

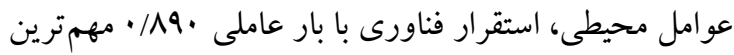
كويه عوامل فرايندى، ياسخخويى سريع با بار عاملى 194/• مهمترين كويه عوامل خروجى، كيفيت خدمات با بار عاملى / مVD

\begin{tabular}{|c|c|c|c|c|c|c|c|c|}
\hline r & 9 & $\Delta$ & $r$ & $r$ & $r$ & 1 & ابعاد & رديف \\
\hline & & & & & & 1 & عوامل ساختارى & 1 \\
\hline & & & & & 1 & | & عوامل رفتارى & r \\
\hline & & & & 1 & - IMA & - /VGA & عوامل محيطى & $r$ \\
\hline & & & 1 & -/AVQ & $\cdot / 1191$ & ./WVF & فرايند گرايى & r \\
\hline & & 1 & - / ^AY & $\cdot / 9 . \cdot$ & $\cdot / M M$ & . & خروجى & $\Delta$ \\
\hline & 1 & $.19 \%$. & .190 & $\cdot / V F$. & $\cdot / \Delta \vee 4$ & .1909 & ي يامد & 9 \\
\hline 1 & $.19 \mathrm{VF}$ &.$/ \Delta 9$. & $\cdot / \Delta F A$ & $\cdot / 4 \cdot 9$ & $\cdot / \Delta 91$ & .1911 & اثر & $\checkmark$ \\
\hline
\end{tabular}

تغييرات متغير وابسته توسط متغيرهاى مستقل صورت مى گيرد. نتايج مطالعه نشان مىدهد MN/N/ از تغييرات مدل

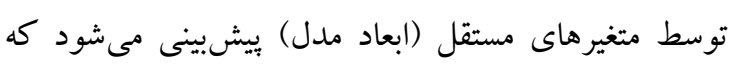

براى بررسى كيفيت مدل از شاخص بررسى افزونگى و ضريب تعيين استفاده گرديد. اعداد مثبت نشانكر كيفيت برديح مناسب مدل هستند. معيار اصلى ارزيابى مدل ساختارى، ضريب تعيين است. اين شاخص نشان مىدهد جند درصد از 
نشان مىدهد مقادير مشاهده شده خوب بازسازىشده و مدل توانايى ييش بينى دارد (ضميمه جدول F).

\begin{tabular}{|c|c|c|}
\hline & & ضميمه جدول †. شاخصهاى بررسى كيفيت مدل \\
\hline 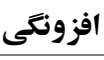 & ضريب تعيين & مدل \\
\hline$\cdot 1099$ & $\cdot / M V$ & مدل بين الملل سازى كسب و كارهاى خدماتى در مناطق مرزى كشور در صنعت توريسم درمانى \\
\hline
\end{tabular}

با استفاده از تكنيك مربعات جزئى و آزمون t بوت ل

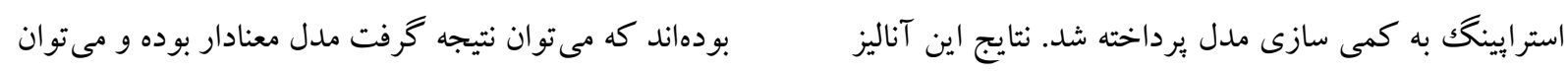

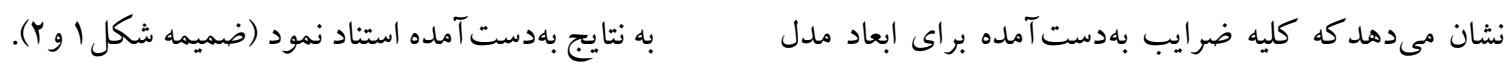

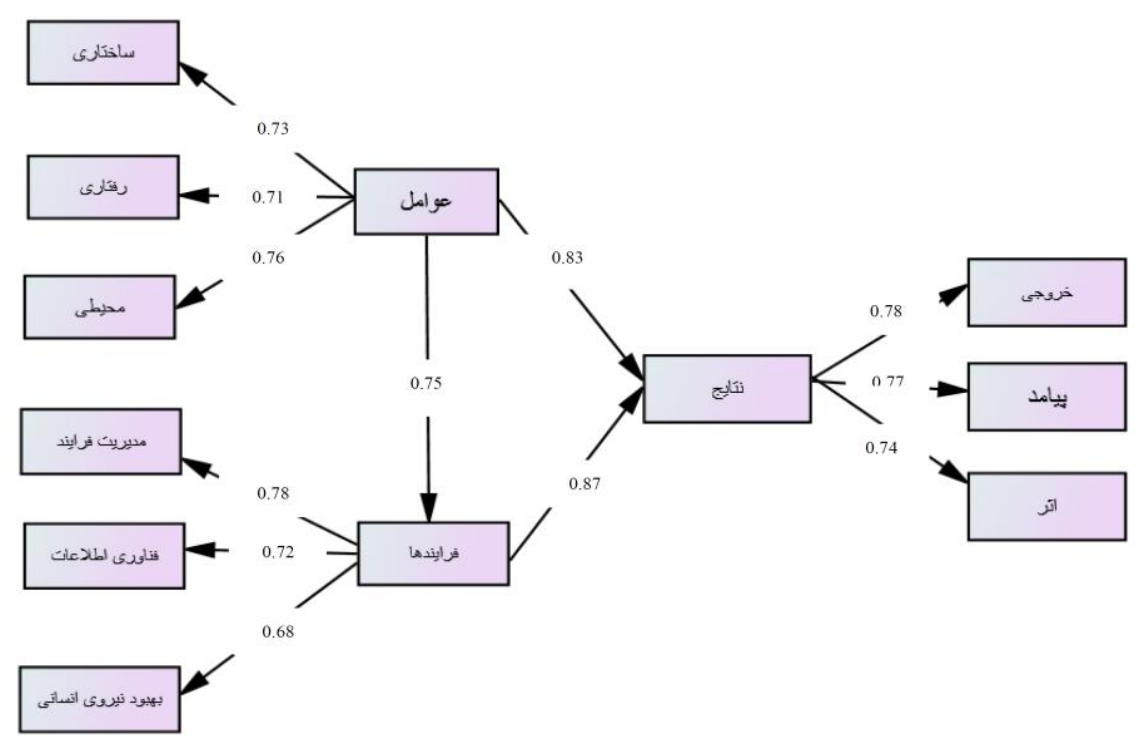

ضميمه شكل ا: روابط على ميان متغيرهاى مدل در حالت تخمين استاندارد 


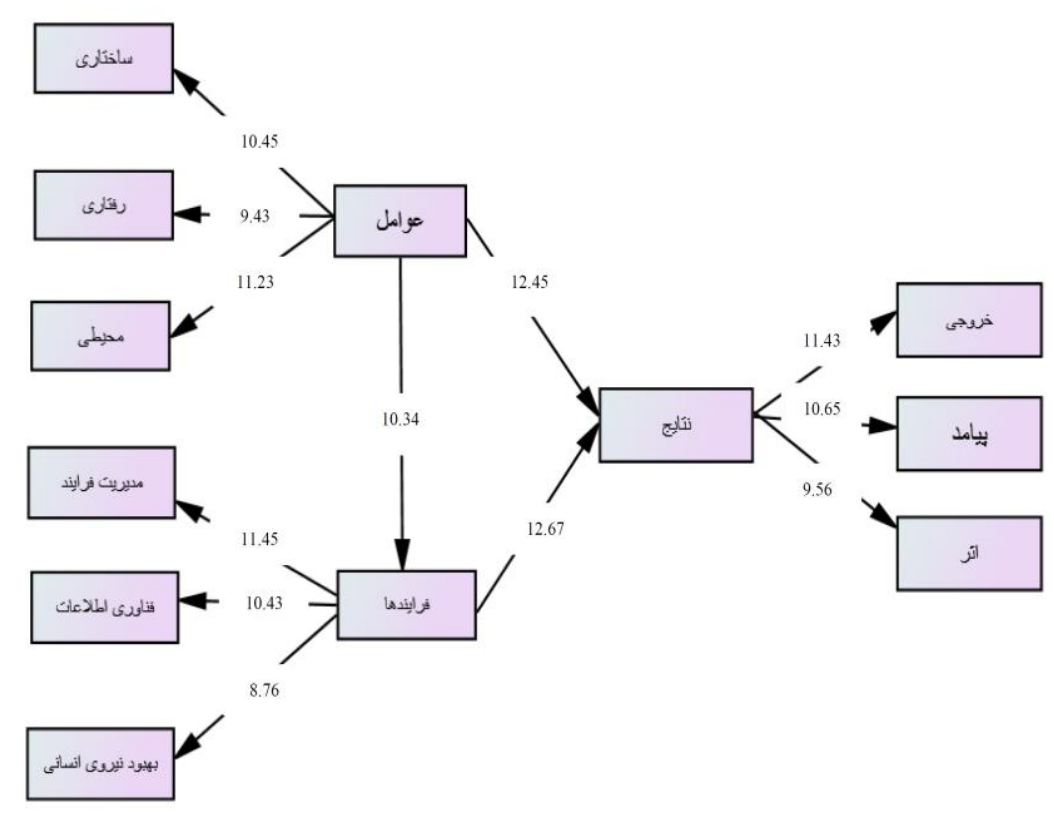

ضميمه شكل r. روابط على ميان متغيرهاى مدل در حالت تخمين معنادارى

بهبود نيروى انسانى) به ميزان AV/ • و مقدار Y I I ب بر روى نتايج تأثير كذار هستند و مىتوان بيان داشت كه روابط صحت لته على موجود درمدل تحقيق تائيد شده و مدل نيز مناسب است

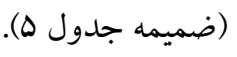

همجنين نتايج آزمون مسير بيان داشت كه كليه عوامل

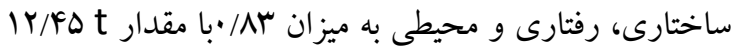
بر روى فرايندها تأثير كذاشته و به ميزان VD/ · و مقدار

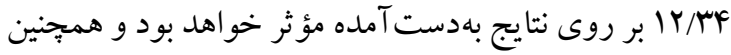
كليه ابعاد فرايندى (مديريت فرايندها، فناورى اطلاعات و

ضميمه جدول ه. نتايج آزمون مسير

\begin{tabular}{|c|c|c|c|c|c|}
\hline نتيجه & Tماره T & ضرايب مسير & به & 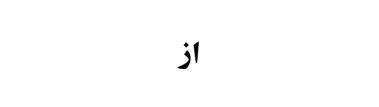 & 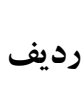 \\
\hline تائيد & $\mid Y / F D$ &.$/ \wedge \mu$ & نتايج (خروجى، ييامد، اثر ) & عوامل (ساختارى، رفتارى، محيطى) & 1 \\
\hline 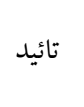 & $1 \cdot / \mu F$ &.$/ \mathrm{V} \Delta$ & فرايندها (مديريت فرايندها، فناورى اطلاعات و بهبود نيروى انسانى) & عوامل (ساختارى، رفتارى، محيطى) & r \\
\hline 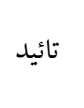 & $1 Y / 9 V$ &.$/ A \vee$ & نتايج (خروجى، ييامد، اثر ) & فرايندها (مديريت فرايندها، فناورى اطلاعات و بهبود نيروى انسانى) & r \\
\hline
\end{tabular}


معيار خطاى RMSEA نيز برابر با ب./ بر آورد شده كه اين مقدار كوجككتر از حد مجاز ^••• است. كه بر اساس برآوردهاى

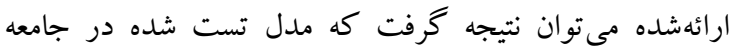

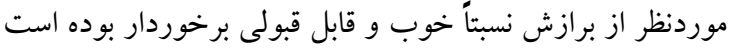
(جدول ضميمه 9).
در نهايت مقادير بهدستآمده از برازش مدل با استفاده از

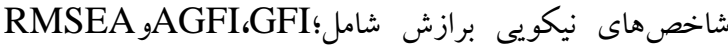
نشان مى دهند كه نتايج مدل قابل اعتماد است. جر اكه شاخصهاى لتراى

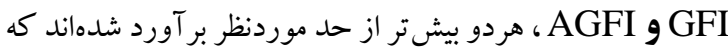

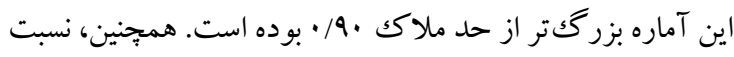

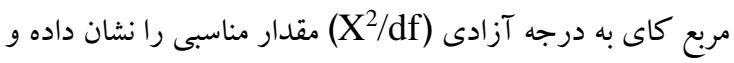

\begin{tabular}{|c|c|c|c|c|}
\hline نتيجه برازش & مقادير يزوهش & ملاكs & نماد & شاخصهاى برازش \\
\hline برازش خوب & $1, \mu r$ & $\leq r$ & $\mathrm{X}^{2} / \mathrm{df}$ & تقسيم كاى-مربع بر درجه آزادى \\
\hline برازش خوب & $\cdot, \cdot r$ & $\leq \cdot / \cdot 1$ & RMSEA & ريشه ميانكين مربعات خطاى بر آورد \\
\hline برازش خوب &.$/ 9 F$ & $\geq \cdot 19$ & GFI & شاخص نيكويى برازش \\
\hline برازش خوب &.$/ 91$ & $\geq \cdot 19$ & AGFI & شاخص نيكويى برازش تعديل شده \\
\hline 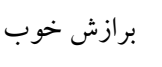 & $\cdot / 90$ & $\geq \cdot / 9$ & CFI & شاخص برازش مقايسه اى \\
\hline برازش خوب & • & $\geq \cdot 19$ & IFI & شاخص برازش افزايشى \\
\hline برازش خوب &.$/ 94$ & $\geq \cdot / 9$ & NFI & شاخص برازش نرم \\
\hline برازش خوب &.$/ 99$ & $\geq \cdot / 9$ & NNFI & شاخص برازش غير نرم \\
\hline
\end{tabular}

كسبو كارهاى خدماتى در مناطق مرزى كشور در صنعت توريسم

با توجه به مطالب عنوان شده، مشخص شد كه با اطمينان هذ٪ كليه درمانى ارائه گر ديد (ضميمه شكل ؟).

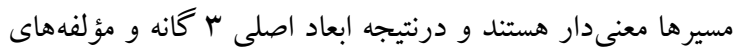

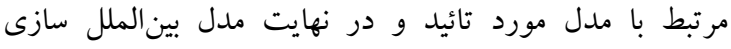

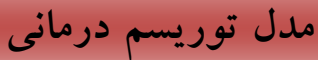

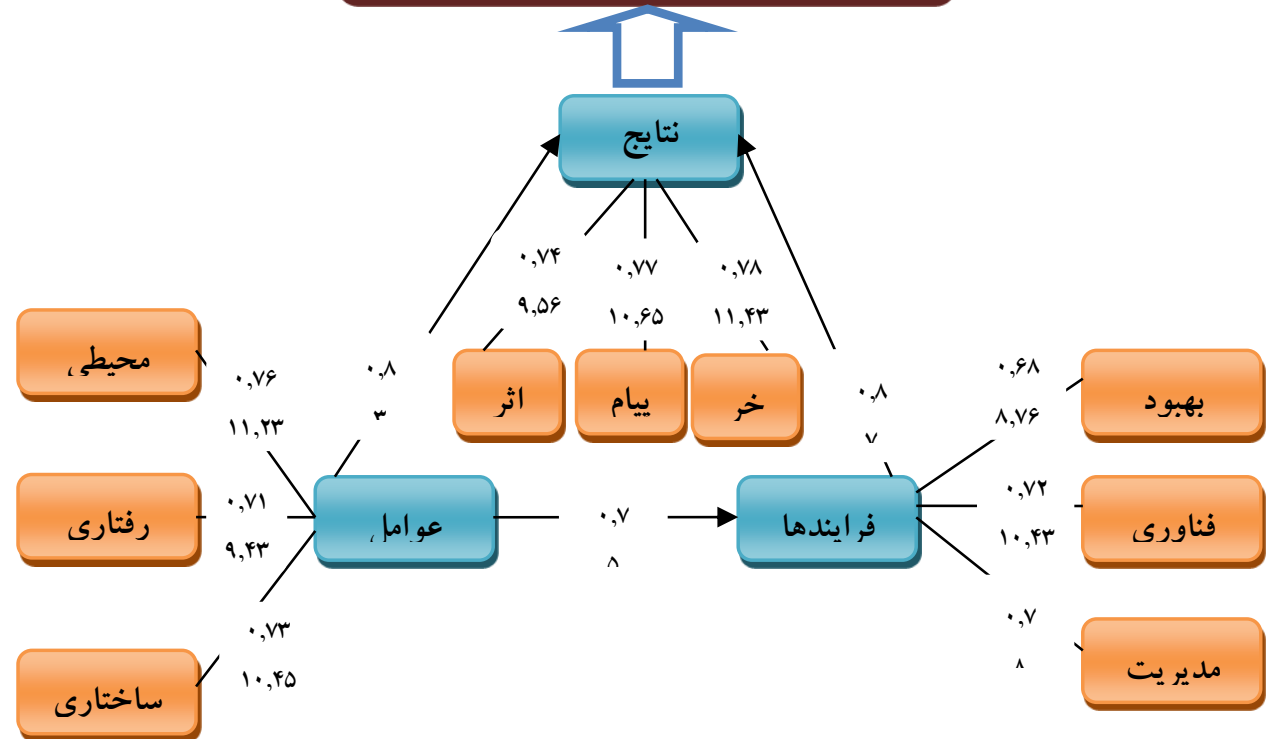

ضميمه شكل "آ مدل بينالملل سازى كسبو كارهاى خدماتى در مناطق مرزى كشوردرصنعت توريسم درمانى 
مطالعه حاضر بيان شد در صورت تغيير نخرش سياستمداران با اصلاح قوانين و تمركز بر افزايش كيفيت و تنوع خدمات

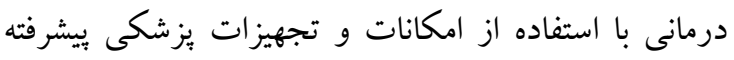

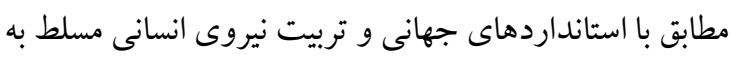

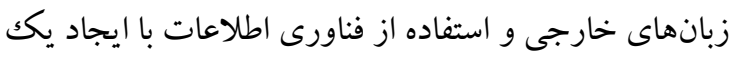

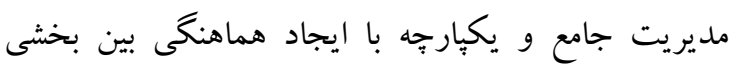

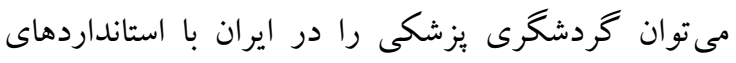

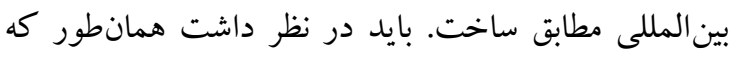

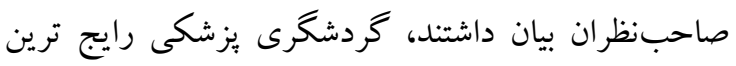

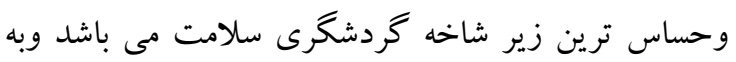

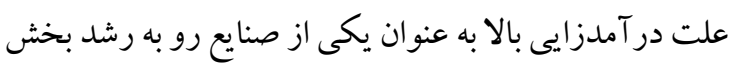

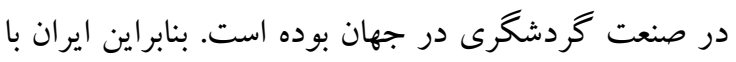

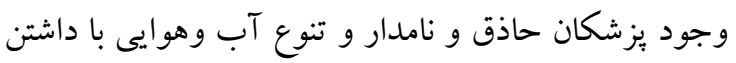

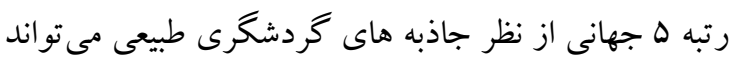
از اين اقتصاد نامريى و ظرفيت جهانى نسبت به توسعه اين صنعت اقدام كرد و ضمن ايجاد اشتغال بايدار وسالم در آمد و ارز آورى قابل توجهى راكسب نمود؛ لذا از طريق مدل مذكور، با بين الملل سازى كسب وكارهاى خدماتى در مناطق مرزى كشور، به عنوان يكك استراتزى توسعه مورد توجه قرار گيرد به طورى كه در مطالعات مختلف نيز بيان شده است كه در زمينٔ گردشخرى درمانى و جذب فرار گردشخران سلامت، همواره بايد به جهار عامل اساسى توجه داشت كه عبارت اند از: توانمندى هاى شاغلين حرفه يزشكى، فناورى هاى روز و استانداردهاى جهانى، اقتصاد درمان و هزينههاى درمانى و مقررات داخلى كشورها(19,

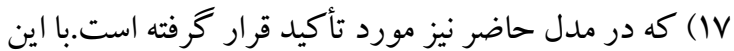

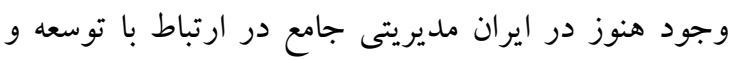
هماهنكى بين بخشهاى مرتبط با توريسم درمانى وجود درد

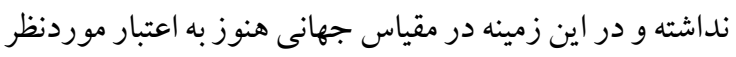

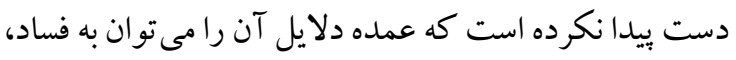
نبود سلامت ادارى ، عدم تنش زدايى، محدويتهاى قانونى
مطالعه حاضر از رويكرد جند گانه براى شناسايى عوامل مؤثر

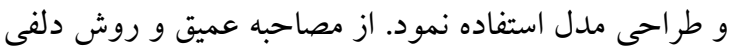
براى شناسايى عوامل مؤثر و از روش تحليل عاملى براى نهايى سازى مدل استفاده شد نشان داد كه عوامل ساختارى، رفتارى

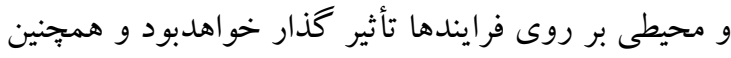
كليه ابعاد فرايندى (مديريت فرايندها، فناورى اطلاعات و

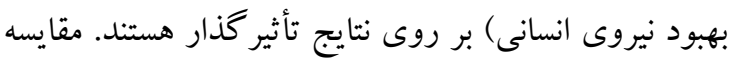

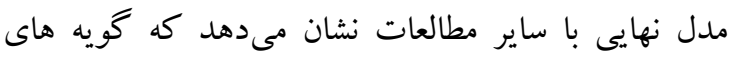
مختلف، مورد تأكيد در ساير مطالعات بوده و در اكثر موارد

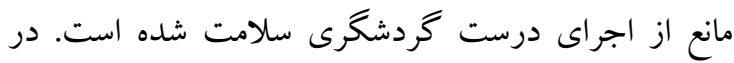
مطالعه بديعى كه با هدف شناسايى و رتبهبندى ردائ راهكارهاى

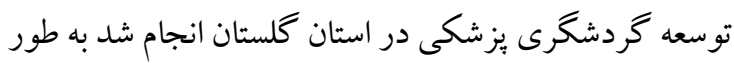

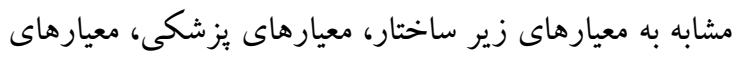

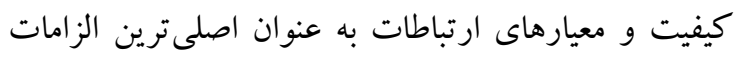
توسعه گردشخرى يز شكى اشاره نمود. بر اساس اين مطالعه

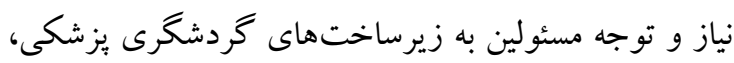

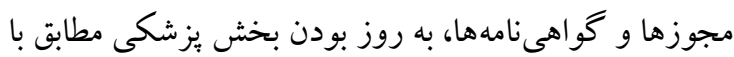
آخرين استانداردهاى كيفى دنيا و اهميت ارتباطات مؤثر و استفاده از ابزارهاى ارتباطى، مىباشد (r) (1). در مطالعه نعمتى

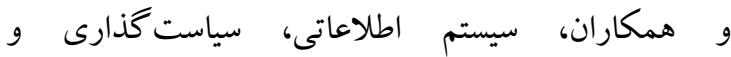
قانون كذارى، زيرساختى، كيفيت خدمات و موانع نيروى

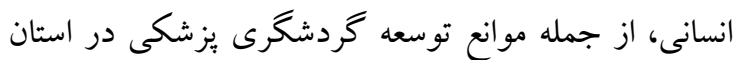
اردبيل بيان شد (IF) كه جز گويه هاى اصلى در مدل نهايى مطالعه حاضر شناسايى شد. تأكيد بر گويه هاى مطالعه حاضر

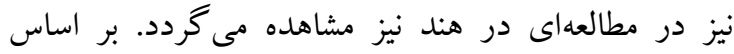
مطالعهاى در هند به سبب داشتن يزشكان و جراحان باتجربه، تسلط كادر درمانى به زبان انكليسى، مجهز شدن به تجهيزات

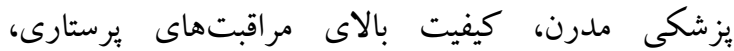
مراقبتهاى اوليه براى جراحىهاى بيّيجيده، به عنوان مزيت رقابتى اين كشور و مقصد كردشگُى براى بيماران از كشورهاى توسعهيافته دانسته است(ها). در مدل مذكور در 


$$
\begin{aligned}
& \text { به سمت بين الملل سازى اقدامات لازم راطى برنامه راهبردى }
\end{aligned}
$$

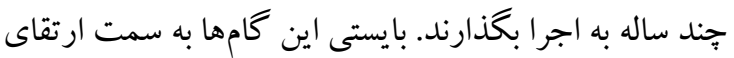

$$
\begin{aligned}
& \text { زيرساختهاى مرتبط با اين بخش، انعقاد قراردادهايى با } \\
& \text { كشورهاى ديخر، استفاده از امكانات و تجهيزات يزشكى و } \\
& \text { كردشخرى بيشرفته و مدرن، مطابق با استانداردهاى جهانى، }
\end{aligned}
$$

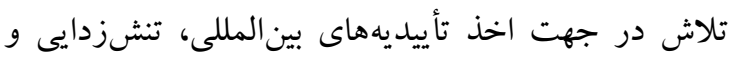

$$
\begin{aligned}
& \text { توسعه روابط سياسى با كشورهاى مختلف و تربيت نيروى } \\
& \text { انسانى در بخش بهداشت و درمان بهمنظور بهبود كيفيت }
\end{aligned}
$$

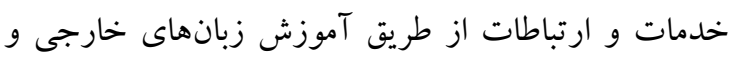

$$
\begin{aligned}
& \text { استفاده گسترده از فناورى اطلاعات و ارتباطات، باشد. }
\end{aligned}
$$

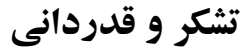

$$
\begin{aligned}
& \text { اين تحقيق حاصل رساله دكتراى مربوط به به آقاى انور }
\end{aligned}
$$

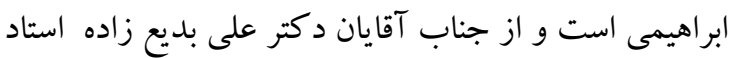

$$
\begin{aligned}
& \text { راهنما و آقاى دكتر كامبيز حيدرى هنزايى بهعنوان مشاور } \\
& \text { حامى علمى تشكر و قدردانى به عمل مى آيد. }
\end{aligned}
$$

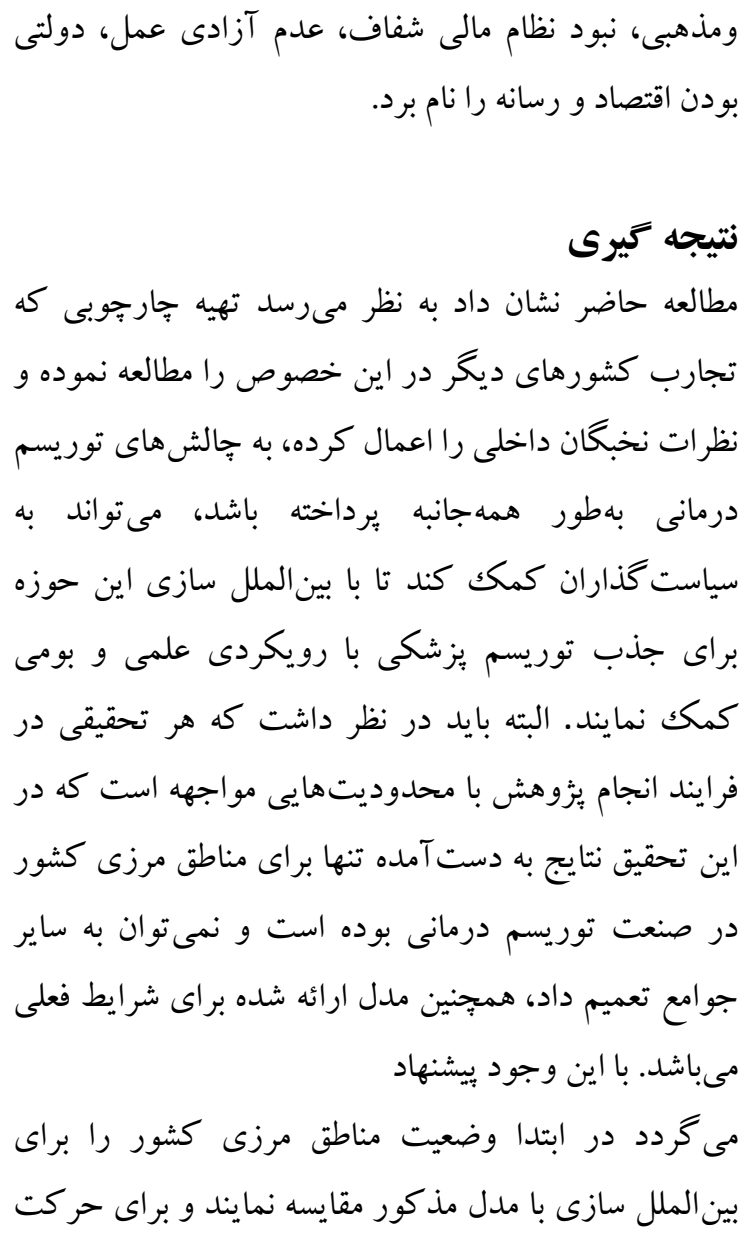

منابع

1.Setiawan M, Surjokusumo S, Ma'soem D, Johan J, Hasyim C, Kurniasih N, et al., editors. Business Centre Development Model of Airport Area in Supporting Airport Sustainability in Indonesia. J Phys Conf Ser. 2018;954(1):212-180.

2.Parnian H, Ziyari K, Mirehie M, Modiri M. Development Strategies of Border Regions with Spatial Planning Approach Case Study: Urmia-Salmas Zone. Scientific-Research Quarterly of Geographical Data (SEPEHR). 2018;26(104):173-84.

3.Tallman S, Luo Y, Buckley PJ. Business models in global competition. GSJ. 2018;8(4):51735 .

4.Casadesus-Masanell R, Ricart JE. From strategy to business models and onto tactics. LRP. 2010;43(2-3):195-215.

5.Teece DJ. Business models, business strategy and innovation. LRP. 2010;43(2-3):172-194.

6.Pangarkar N. Internationalization and performance of small-and medium-sized enterprises. J WORLD BUS. 2008;43(4):475-85.

7.Hubner W. SME. development in countries of central Asia (Kazakhstan, Kyrgyzstan, and Uzbekistan): Constraints, cultural aspects and role of international assistance. United Nations Industrial Development Organization (UNIDO). 2000; 23(102):78-50.

8.Wang Y, Jia F, Schoenherr T, Gong Y. Supply chain-based business model innovation: The case of a cross-border E-commerce company. Sustainability. 2018;10(12):4362.

هبلم علمى دانشكاه علوه بِزشكى كردستان / دوره بيست و شش / آذر و دى م。ع|| 
9.Karagiannis D, LeMaster N. eBusiness in Healthcare: From eProcurement to Supply Chain Management: JSSM. 2007;8(5):90-75.

10.Calof JL, Beamish PW. Adapting to foreign markets: Explaining internationalization. IBR. 1995;4(2):115-31.

11.Badiei F, Ebrahimi A, Didekhani H. Medical tourism development in golestan province; an assessment of identified solutions. NMRJ .2017;6(4):25-36.

12.NematiV, Ebrahimpour H, Babaee Y, Abbasgholizadeh N. Assessing barriers to the development of medical tourism case study: j.health. 2016;7(2):118-33.

13.Pál Á, Nagy G, Pál V. The impact of border-zone location on spatial features of szeged's trade. New Results of Cross-Border Cooperation. 2011:51-9.

14.Medhekar A, Wong HY, Hall J. Innovation in medical tourism service marketing: A case of India. Innovations in services marketing and management: Strategies for emerging economies: IGI Global; 2014;6(2): 49-66.

15.Braveman P. What is health equity: and how does a life-course approach take us further toward it? . JMCH. 2014;18(2):366-72.

16.Chou SY, Kiser AI, Rodriguez EL. An expectation confirmation perspective of medical tourism. JoSS. 2012;4(2):299-318.

17.Lambert SC. Deconstructing business model frameworks using a reference model: Centre for Accounting, Governance and Sustainability, University of South ;2012.4:1019-1042. 